\title{
International Financial Contagion: The Role of the UK*
}

\author{
Abdullah Yalama** \\ Eskişehir Osmangazi University
}

\begin{abstract}
The purpose of this study is to consider the role of the United Kingdom in the effect of transferring the global credit crisis from the United States to Turkey. This study compares the results of the most commonly used contagion models, which are known as Forbes and Rigobon model and Dungey, Fry, Gonzalez-Hermosillo and Martin model. Moreover, this study presents evidence regarding the manner of transmission of the crisis. This study confirmed that there is a strong contagion effect from the United States to Turkey and the United Kingdom. The importance of the United Kingdom in transferring this shock is captured in the DFGM model more accurately than in the FR model. Finally, the global credit crisis is transferred to Turkey through financial linkages rather than trade linkages. The existence and direction of contagion create an opportunity for investors to use international hedging strategies and asset allocation.
\end{abstract}

Keywords: contagion, global credit crisis, DFGM model, FR model

JEL Classification: F30, G15.

\section{Finansal Krizlerin Uluslararası Bulaşıcılığı: İngiltere’nin Rolü}

\section{Özet}

Bu çalışmanın amacı küresel kredi krizinin Amerika'dan Türkiye'ye transfer edilmesinde İngiltere'nin rolünü test etmektir. Bu çalışmada krizlerin transfer mekanizmalarının analizi adına literatürde sıklıkla uygulama alanı bulan bulaşıcılık modellerinden Forbes ve Rigobon modeli ile Dungey, Fry, Gonzalez-Hermosillo ve Martin modellerinin sonuçları karşılaştırmıştır. Çalışmanın sonucunda küresel kredi krizinin Amerika'dan İngiltere ve Türkiye'ye doğru bir bulaşıcılık etkisinin varlığı vurgulanmıştır. İngiltere'nin bu küresel kredi krizini Amerika'dan Türkiye'ye transfer edilmesinde üstlendiği rolle ilgili kanıtlar daha çok DFGM modeli ile yakalanmıştır. Son olarak ise küresel kredi krizinin Türkiye ticari değil finansal yolla transfer edildiğine yönelik bulgular vurgulanmıştır.

Anahtar kelimeler: bulaşıcılık, küresel kredi krizi, DFGM modeli, FR modeli.

The author acknowledges support from an Eskisehir Osmangazi University Research Grant (200817046) and would like to thank Prof. Mardi Dungey for sharing her gauss codes. I am grateful to Sibel Çelik for her excellent research assistance and the participants in the 13th National Finance Conference.

** Abdullah Yalama is an Associate Professor in the Department of Management at Eskişehir Osmangazi University, 26480, Meşelik-Eskişehir, Turkey. E-mail: abdullah.yalama@gmail.com 
$\mathrm{T}$ he global credit crunch of 2007 and 2008 spread through a wide variety of financial asset markets and across geographic borders and has infected both developed and emerging markets. The time of the origin of the global credit crunch was July 2007 when Bear Stearns announced the collapse of its hedge funds. In August 2007, the largest bank in France, BNP Paribas, declared that they had ceased valuing three funds. This announcement prompted a startled reaction in the financial markets. Thus, the European Central Bank injected 95 million euros into the market. On the same days, an increase in the difference between LIBOR and the overnight interest rate exacerbated the problem in global credit markets. Global bankruptcies occurred successively. Although the trigger for these events appears to lie in the securitization of sub-prime mortgage-backed securities in the US, credit risk transfer products, including collateralized debt obligations (CDOs), have emerged as also likely triggers. The collapse of confidence in these products resulted in important changes in the balance sheets of financial intermediaries and consequent increases in the costs of funds and equity prices. International banking linkages and international portfolio diversification contributed to spreading the turmoil across geographic barriers.

In the early part of the credit crunch, the United Kingdom (UK) markets were significantly affected. The nationalization of Northern Rock was one of the earliest such events in this crisis, but other European financial institutions seemed relatively insulated. However, the spread of the crisis to globally tighter credit conditions and into international equity markets led to more substantial effects. Following the collapse of Lehman Brothers in particular, in September 2008, weaknesses in continental European financial institutions became more apparent, and a number of rescue packages were enacted.

The literature indicates that the Asian crisis of 1997-1998 spawned a number of proposals for the reform of international financial architecture, particularly in response to the spread of the crisis through contagion. Contagion between asset markets during financial crises is defined as the transmission of shocks via newly opened channels that are associated with crisis events (Dungey et al., 2005). Contagion between capital markets has been subject to extensive empirical research. Most of the related research focuses on volatility spillovers in the context of financial crises (Bekaert and Harvey, 2003, Forbes and Rigobon, 2002, Dungey et al., 2005). Understanding contagion effects is vital for portfolio diversification and hedging strategies (i.e., investor behavior).

This paper fills a gap in the literature by extending the recent framework of contagion on emerging markets to formally determining whether the UK had a role in transferring volatility from the United States (US) to Turkey (TR). Additionally, the paper compares the results of the most commonly used contagion models, FR and DFGM. Finally, the paper presents some evidence regarding the manner of the transmission of the global credit crisis. Thus, the paper focuses on futures markets rather than spot markets for the following reasons: first, futures markets respond to new information more rapidly than spot markets (Stoll and Whaley, 1990). Second, futures market data reduce nonsynchronous trading problems (Wu et al., 2005). The results showed that US volatility was transferred to TR via the UK. The DFGM model captures this contagion more accurately than the FR model. The global credit crisis was transferred to Turkey through financial 
linkages rather than trade linkages. The existence and direction of contagion create an opportunity for investors to use international hedging strategies and asset allocation.

The remainder of this paper proceeds as follows. Section 2 presents a review of the relevant literature. Section 3 introduces the data, and section 4 presents the empirical methodology. Section 5 presents the empirical results of the investigation of the role of the UK in transferring volatility from the US to TR. Finally, section 6 presents some concluding comments and suggests further research directions.

\section{Literature Review}

The identification of contagion effects during financial crises has a relatively long history, with origins that may be traced to the works of Sharpe (1964) and Grubel and Fadner (1971). Although these authors do not use "contagion" in their research, they offer an insight into contagion research. Contagion is described as the transmission of unanticipated local shocks from one country to another (Dungey et al., 2005).

More recent work on the transmission of financial market shocks has included studies on common factors and correlations between asset market returns, especially the studies by King and Wadhini (1990) and Bekaert and Hodrick (1992). However, formal work on financial crises and the definition of contagion have emerged more recently, particularly following the Asian crisis of 1997-1998, especially in the work by Kaminsky and Reinhart (1999) and Bordo and Eichengreen (1999) who specifically examine the history of crises and crisis models, and authors who consider theoretical models of contagion itself, such as Calvo and Mendoza (2000) and Kodres and Pritsker (2002). Empirical implementation of specific tests of contagion are more recent: the most prominent papers include those of Dungey and Martin (2007); Bae, Karolyi and Stulz (2003); Bekaert, Harvey and Ng (2003); Forbes and Rigobon (2002); Corsetti, Pericoli and Sbracia (2002); and Eichengreen, Rose and Wyplosz (1995, 1996). Dungey et al. (2005) showed how many of these tests can be nested within a factor model framework and highlighted the differences between these tests.

Moreover, empirical implementation of the contagion test applies to many different markets [stock markets (King and Wadhwani, 1990; Forbes and Rigobon, 2002), foreign exchange markets (Cerra and Saxena, 2002; Dungey and Martin, 2004; Dungey et al., 2004; Tai, 2004), bond markets (Dungey et al., 2006), and futures markets (Tai, 2003)]. When we examine the empirical literature on the nature of contagion, we find that some empirical studies show the crisis transfer mechanisms from one country to another country based on trade linkages (Glick and Rose, 1999) or financial linkages (Van Rijckeghem and Weder, 2001). Crises generally spread from developed countries to developing countries (Kaminsky and Reinhard, 2007). Additionally, most of the empirical contagion literature shows that contagion effects are regional (Dungey et al., 2006); however, some studies indicate that this contagion effect is interregional (Dungey and Martin, 2007).

Studies on the global credit crunch are beginning to appear in the literature. For example, Dungey (2009) examines contagion among the US, UK, European, Japanese and Australian money markets and stock exchange markets during the credit crunch 
period. Dungey (2009) separates the sample period into the reference period and the credit crunch period and designates the beginning of the credit crunch period as 17 July 2007, which was the date on which problems related to Bear Stearns hedge funds were announced. Dungey (2009) presents three important findings. First, an increase in the volatility of global shocks is transmitted to all markets in the same manner as during the non-crisis period. Second, the contribution of this contagion to the volatility in the non-US markets is consistent with the results that were found for the contribution of contagion that was evidenced for previous crises. Third, the US equity market appears to play a role in absorbing shocks from the US money market and distributes these shocks to other markets. Dungey (2009) has also shown that the global credit crunch has spread from the US to developed countries in addition to developing countries.

Horta et al. (2008) analyze the influence of the US subprime mortgage crisis on Canadian, Japanese, Italian, France, UK, German and Portuguese stock exchange markets using copula models. These researchers separate the sample period into the non-crisis period (1 January 2005-1 August 2007) and the crisis period (1 August 2007-29 February 2008). The results confirm a remarkable contagion effect for Canada, Japan, Italy, France and the UK, but find the effect not significant for Germany.

Longstaff (2008) focused on stock exchange markets and bond markets using the ABX index data maintained by Markit Group Ltd., 1- and 10-year maturity bond yields, and US index returns. Longstaff obtains important findings concerning contagion in financial markets and concludes that contagion effects initially spread from lower-rated $\mathrm{ABX}$ indices to higher-rated $\mathrm{ABX}$ indices and subsequently spread from the subprime markets to the Treasury bond and stock markets.

When we evaluate earlier crises and the subprime mortgage crisis together, we realize that studies related to the contagion effect of crises primarily focus on developed countries and spot markets. This paper differs from other studies in testing whether the UK had a role in transferring volatility from the US to TR.

\section{Data}

The data set comprises daily returns of the Istanbul Stock Exchange futures contracts traded on the Turkish Derivative Exchange Market (ISE-30 for Turkey), Standard \& Poor's futures contracts traded on the Chicago Board of Trade Market (S\&P 500 for the US), the Financial Times and the London Stock Exchange futures contracts traded on the London International Financial Futures Exchange Market (FTSE-100 for the UK) and the Nikkei future contract traded in the Osaka Securities Exchange Market (NIKKEI-225 for Japan). ${ }^{[1]}$ The data were obtained for the period between 4 February 2005 and 25 March 2009 from Datastream. The Datastream codes are ISPCS00, LSXCS00, and ONACS00 for S\&P 500, FTSE-100 and NIKKEI-225, respectively. Specifically, the ISE-30 futures data were obtained from the Turkish Derivative Exchange Market. ${ }^{[2]}$

\footnotetext{
[1] NIKKEI-225 is used as an additional conditioning variable for testing contagion among Turkey, the US and the UK (see Dungey et al., 2005).

${ }^{[2]} \mathrm{http} / / /$ www.vob.org.tr. For ISE-30, the data are a continuous series of futures settlement prices that begin at the nearest
} 
We calculate index returns as follows:

$\ln \left(\frac{P_{t}}{P_{t-1}}\right) \times 100$

Equity returns are calculated as the differences in the natural logarithms of daily equity prices and multiplied by 100 to express the returns as a percentage.

\section{Detecting Crisis Periods}

The detection of crisis periods is controversial in the literature (Kaminsky and Schmukler, 1999). Some studies attempt to determine crisis periods using distributions of data (Favero and Giavazzi, 2002), whereas some studies attempt to determine crisis periods using threshold models (Lowell, Neu and Tong, 1998) or regime switching models which offer a Bayesian framework (Hamilton, 1989; Hansen 1992). However, based on the empirical evidence for the Asian crisis, neither model is substantial (Dungey et al., 2005). Many researchers prefer to identify crisis periods based on a news framework (Dungey, 2009). In this study, we also prefer to consider a news framework for identifying the crisis period. When we examine the existing literature, we observe that the first sign of the global credit crisis was given on 17 July 2007.

Consistent with the findings in the literature (Dungey, 2009, Dungey and Yalama, 2012), the crisis period began 17 July 2007, which corresponds to the date on which Bear Stearns announced the collapse of its hedge funds. To obtain stable or benchmark period data for the two years prior to the crisis data, this study considers the pre-crisis period from 4 February 2005 to 16 July 2007 and the crisis period from 17 July 2007 to 25 March 2009. The commencement of this period is consistent with the turning point in the US monetary policy cycle. ${ }^{[3]}$

The data begin on 4 February 2005 because the Turkish Derivative Exchange Market data begin on this date.

For untraded days between these periods, either the deletion of missing observations or the replacement of missing observations with previous market observations is suggested (Dungey et al., 2005). In this study, untraded days are deleted. Otherwise, unobservable days may mislead us with regard to the transfer of volatility between markets (Dungey and Tambakis, 2005).

contract month and continue until a contract reaches its expiration date. At this point, the next contract month is taken. These contracts comprise a continuous series of futures settlement prices that begin at the nearest contract month and generate the initial values for the continuous series until either the contracts reach their expiration dates or until the first business day of the actual contract month. At this point, the next contract month is taken (Engle and Colacito, 2006).

${ }^{[3]}$ For robustness check, we additionally performed the Chow-test (1960) to test our a priori decision about the pre-crisis and crisis periods. The F-statistics are 40.42 (p: 0,0000), 43.85 (p: 0,0000), 41.26 (p: 0,0000) for US, UK, and Turkey respectively. Thus based on p-values, the null hypothesis of no breakpoints at the time of 4 February 2005-16 July 2007 and 17 July 2007-25 March 2009 is rejected at a 1\% level. 


\section{Methodology}

\section{Forbes and Rigobon Bivariate Test (2002)}

The FR test is essentially a test of the statistical significance of a change in the correlation coefficient between exogenously chosen non-crisis and crisis period samples. The insight of Forbes and Rigobon was to adjust for the bias in such a test between raw correlation statistics that may be caused by higher volatility during a crisis period. The returns on two assets $\left\{\mathrm{r}_{1, \mathrm{v}} \mathrm{r}_{2, \mathrm{t}}\right\}$ that are first filtered via a $\operatorname{VAR}(1)$ and the correlations between the residuals are examined for changes in structure between the non-crisis period (considered to be the entire sample) and the crisis period to control for the usual levels of interaction between markets. Under the null hypothesis of no contagion, the correlation coefficients do not change; that is, $H_{0}: \rho_{n c}=v_{c}$, where $p_{n c}$ is the non-crisis period correlation coefficient, and $v_{c}$ represents the crisis period correlation coefficient adjusted for heteroskedasticity.

$$
v_{c}=\frac{\hat{\rho}_{c}}{\sqrt{1+\left(\frac{s_{c}^{2}-s_{n c}^{2}}{s_{n c}^{2}}\right)\left(1-\hat{\rho}_{c}^{2}\right)}}
$$

where $p_{c}$ is the crisis sample correlation coefficient, and $s^{2}$ denotes the sample variances. Under the null hypothesis, the FR statistic is as follows:

$$
\mathrm{FR}=\frac{\frac{1}{2} \ln \left(\frac{1+\hat{v}_{c}}{1-\hat{v}_{c}}\right)-\frac{1}{2} \ln \left(\frac{1+\hat{\rho}_{n c}}{1-\hat{\rho}_{n c}}\right)}{\sqrt{\frac{1}{T_{c}-3}+\frac{1}{T_{n c}-3}}} \sim N(0,1)
$$

where $T_{c}$ and $T_{n c}$ are the number of observations in the crisis and non-crisis periods, respectively.

\section{Bivariate DFGM (2005) test}

This study used the bivariate unanticipated shock model that was developed by Dungey, Fry, Gonzalez-Hermosillo and Martin (2002a,b and 2005) to test contagion. $\mathrm{b}_{\mathrm{i}, \mathrm{t}}$ represents an asset return during the crisis period, and $\mathrm{a}_{\mathrm{i}, \mathrm{t}}$ represents an asset return during the non-crisis period.

Let us consider the case of contagion from country 1 to country 2 . The factor model is now augmented as follows:

$$
\begin{aligned}
& b_{1, t}=\lambda_{1} w_{t}+\beta_{1} \zeta_{1, t} \\
& b_{2, t}=\lambda_{2} w_{t}+\beta_{2} \zeta_{2, t}+\gamma_{1, t}
\end{aligned}
$$


$w_{t}$ refers to a world factor and represents common shocks that affect all asset returns. For the sake of simplicity, $w_{t}$ is assumed to have a zero mean and unit variance. $b_{2, t}$ includes the contagion effect that resulted from unanticipated local shocks in the stock market of country 1 . This effect is measured by the parameter $\gamma$. All basic empirical models test the statistical significance of the parameter $\gamma$.

The bivariate unanticipated shock model of the DFGM test focuses on changes in the volatilities of asset returns. The covariances between the returns of country 1 and country 2 during the crisis period are as follows:

$E\left[b_{1, t} b_{2, t}\right]=\lambda_{1} \lambda_{2}+\not \beta_{1}$

(Equation 4)

When we compare the covariance of the non-crisis period with the covariance of the crisis period, the changes in covariance are as follows:

$E\left[b_{1, t} b_{2, t}\right]-E\left[a_{1, t} a_{2, t}\right]=\mathscr{\beta}_{1}$

(Equation 5)

If $\gamma>0$, then there is an increase in the covariances of returns during the crisis period because of the assumption that $\beta_{1}>0$, as is usually observed in the data. However, $\gamma<0$ is possible, in which there would be a decrease in covariance during the crisis period. Both situations are valid because both situations demonstrate the presence of contagion that results from unanticipated shocks. As a result, contagion is tested by $\gamma=0$ in equation $3 .^{[4]}$

$\gamma=0$

(Equation 6)

\section{Empirical Findings}

Descriptive statistics for the data are given in Table 1. The sample period is divided into three sub-periods: the pre-crisis period (4 February 2005-16 July 2007), the crisis period (17 July 2007-25 March 2009) and the total period (4 February 2005-25 March 2009). The descriptive statistics show that the average returns of the three countries decrease during the crisis period. Returns are positive in the pre-crisis period, whereas average returns become negative during the crisis period. The standard deviations of the equity market returns for all countries increase between the stable and crisis periods. For example, the standard deviation of the returns for the US is 0.667 in the pre-crisis period and 2.301 in the crisis period, the standard deviation of the returns for Turkey is 1.642 in the pre-crisis period and 2.791 in the crisis period, and the standard deviation of the returns for the UK is 0.696 in the pre-crisis period and 2.118 in the crisis period. The extreme minimum and maximum levels of all countries increased during the crisis period.

\footnotetext{
${ }^{[4]}$ http://www.vob.org.tr. For ISE-30, the data are a continuous series of futures settlement prices that begin at the nearest contract month and continue until a contract reaches its expiration date. At this point, the next contract month is taken. These contracts comprise a continuous series of futures settlement prices that begin at the nearest contract month and generate the initial values for the continuous series until either the contracts reach their expiration dates or until the first business day of the actual contract month. At this point, the next contract month is taken (Engle and Colacito, 2006).
} 
Table 1

Descriptive Statistics for Returns

\begin{tabular}{l|l|r|r|r|r|r}
\hline Index & Sample Period & Mean & Observ. & S. Dev. & Max. & Min. \\
\hline \multirow{2}{*}{ US } & Pre-crisis Period & 0.042 & 619.000 & 0.667 & 2.113 & -4.025 \\
& Crisis Period & -0.155 & 425.000 & 2.301 & 13.197 & -10.400 \\
& Total & -0.038 & 1044.000 & 1.556 & 13.197 & -10.400 \\
\hline \multirow{2}{*}{ UK } & Pre-crisis Period & 0.050 & 619.000 & 0.696 & 2.275 & -2.927 \\
& Crisis Period & -0.130 & 425.000 & 2.118 & 9.580 & -9.699 \\
& Total & -0.023 & 1044.000 & 1.454 & 9.580 & -9.699 \\
\hline \multirow{2}{*}{ Turkey } & Pre-crisis Period & 0.098 & 619.000 & 1.642 & 6.674 & -8.189 \\
& Crisis Period & -0.164 & 425.000 & 2.791 & 9.657 & -9.972 \\
& Total & -0.009 & 1044.000 & 2.185 & 9.657 & -9.972 \\
\hline
\end{tabular}

Table 2 provides the covariance structure for the equity returns of all countries during the crisis, pre-crisis, and total periods. Table 2 shows that both the variance and covariance between equity returns increase during the crises period. For example, the variance in the returns in the US, which is the most dramatic variance, increases from nearly $0.443 \%$ in the pre-crisis period to more than $5.282 \%$ during the crisis. This variance for Turkey and the UK increase from nearly $2.691 \%$ and $0.483 \%$ during the pre-crisis period to more than $7.772 \%$ and $4.473 \%$ during the crisis period, respectively.

In addition to variance, the covariance between equity returns across countries increases during the crisis period, and this increase indicates interdependence from contagion. This result additionally offers evidence to support the transmission of the crisis through financial linkages.

For the pre-crisis period, all of the covariance values are less than $1 \%$. In the crisis period, the largest covariance is $4.473 \%$ between Turkey and the UK, whereas the smallest covariance is $2.676 \%$ between Turkey and the US. 
Table 2

Covariances between Returns: Pre-crisis Period (4 February 2005-16 July 2007), Crisis Period (17 July 2007-25 March 2009), and Total Period (4 February 2005-25 March 2009)

\begin{tabular}{r|r|r|r}
\hline & US & UK & Turkey \\
\hline \multicolumn{3}{|c}{ Pre-crisis Period } \\
\hline US & 0.443904 & 0.216951 & 0.180500 \\
UK & 0.216951 & 0.483451 & 0.534993 \\
Turkey & 0.180500 & 0.534993 & 2.691236 \\
\hline \multicolumn{3}{|c}{ Crisis Period } \\
\hline US & 5.282333 & 2.859655 & 2.676175 \\
UK & 2.859655 & 4.473399 & 4.062378 \\
Turkey & 2.676175 & 4.062378 & 7.772704 \\
\hline & & Total Period \\
\hline US & 2.419758 & 1.299639 & 1.207349 \\
UK & 1.299639 & 2.113156 & 1.979934 \\
Turkey & 1.207349 & 1.979934 & 4.771020 \\
\hline
\end{tabular}

This study presents the empirical results of the most commonly used contagion tests: the FR results in Table 3 and the DFGM results in Table 4. The FR test results are presented in Table 3 under the null hypothesis of no contagion and indicate no significant contagion from the US to Turkey or the UK and vice versa.

Table 3

FR Test Results: Pre-crisis Period (4 February 2005-16 July 2007), Crisis Period (17 July 2007-25 March 2009), and Total Period (4 February 2005-25 March 2009)

\begin{tabular}{l|r|r|r}
\hline \multirow{2}{*}{ Contagion (from) } & US & $\begin{array}{r}\text { Contagion (to) } \\
\text { UK }\end{array}$ & Turkey \\
\hline \multirow{2}{*}{ US } & - & -3.392 & -1.191 \\
& & $(0.999)$ & $(0.883)$ \\
\hline \multirow{2}{*}{ UK } & -3.209 & & -1.682 \\
& $(0.999)$ & - & $(0.954)$ \\
\hline \multirow{2}{*}{ Turkey } & -0.265 & -0.508 & - \\
\hline
\end{tabular}

\% $p$ values are in parentheses.

\# The Japanese index (NIKKEI-225) is used as an additional conditioning variable for testing contagion among Turkey, the US and the UK (see Dungey et al., 2005).

In contrast with the FR test, the DFGM test captures a significant contagion effect from the US to Turkey or the UK and vice versa. Further details reveal that: DFGM captures the contagion effect from the US to Turkey, from the US to the UK; from the UK to the US, from the UK to Turkey, from Turkey to the US, and from Turkey to the UK. 
Table 4

DFGM Test Results: Pre-crisis Period (4 February 2005-16 July 2007), Crisis Period (17 July 2007-25 March 2009), and Total Period (4 February 2005-25 March 2009)

\begin{tabular}{l|r|r|r}
\hline Contagion (from) & US & $\begin{array}{r}\text { Contagion (to) } \\
\text { UK }\end{array}$ & Turkey \\
\hline US & - & $\begin{array}{r}166.360 \\
(0.000) * * *\end{array}$ & $\begin{array}{r}16.446 \\
(0.000) * * *\end{array}$ \\
\hline UK & 389.494 & & 15.029 \\
\hline Turkey & $(0.000) * * *$ & & $(0.000) * * *$ \\
\hline
\end{tabular}

$\left[{ }^{*}\right],\left[{ }^{* *}\right]$, and $\left[^{* * *}\right]$ indicate significance at the $10 \%, 5 \%$ and $1 \%$ levels, respectively.

${ }^{\%} \mathrm{p}$ values are in parentheses.

\# The Japanese index (NIKKEI-225) is used as an additional conditioning variable for testing contagion among Turkey, the US and the UK.

When we examine only Table 4, we cannot determine the transfer mechanism of shocks; thus, this situation increases the difficulty of obtaining an accurate analysis. The DFGM test provides detailed information regarding the transfer mechanism of shocks. The unconditional volatility decompositions using the DFGM approach are presented in Table 5. This table provides the proportionate contributions (expressed as a percentage) of each of the factors in the model given by equation (3), which is estimated for both the pre-crisis and crisis periods.

The results for the pre-crisis period show that there were opportunities for portfolio diversification across the three countries, with country-specific factors accounting for between $7 \%$ and $76 \%$ of volatility in this period. However, the crisis period results show substantial contagion. In particular, contagion appears to play a strong role in transmissions from the US to both Turkey $(51.7 \%)$ and the UK $(81.9 \%)$ and from the UK to the US $(71.4 \%)$ and Turkey $(14.2 \%)$. In contrast, there is little support from Turkey to the US $(17.7 \%)$ or the UK $(5.5 \%)$. This preliminary analysis suggests that the contagion effects were channeled into Turkey from both the US and the UK and that the UK had an important role in transferring the shock from the US to Turkey. 
Table 5

Unconditional Volatility Decompositions Expressed as Percentages of the Total from 2005 to 2009: Pre-crisis Period (4 February 2005-16 July 2007), Crisis Period (17 July 2007-25 March 2009), and Total Period (4 February 2005-25 March 2009)

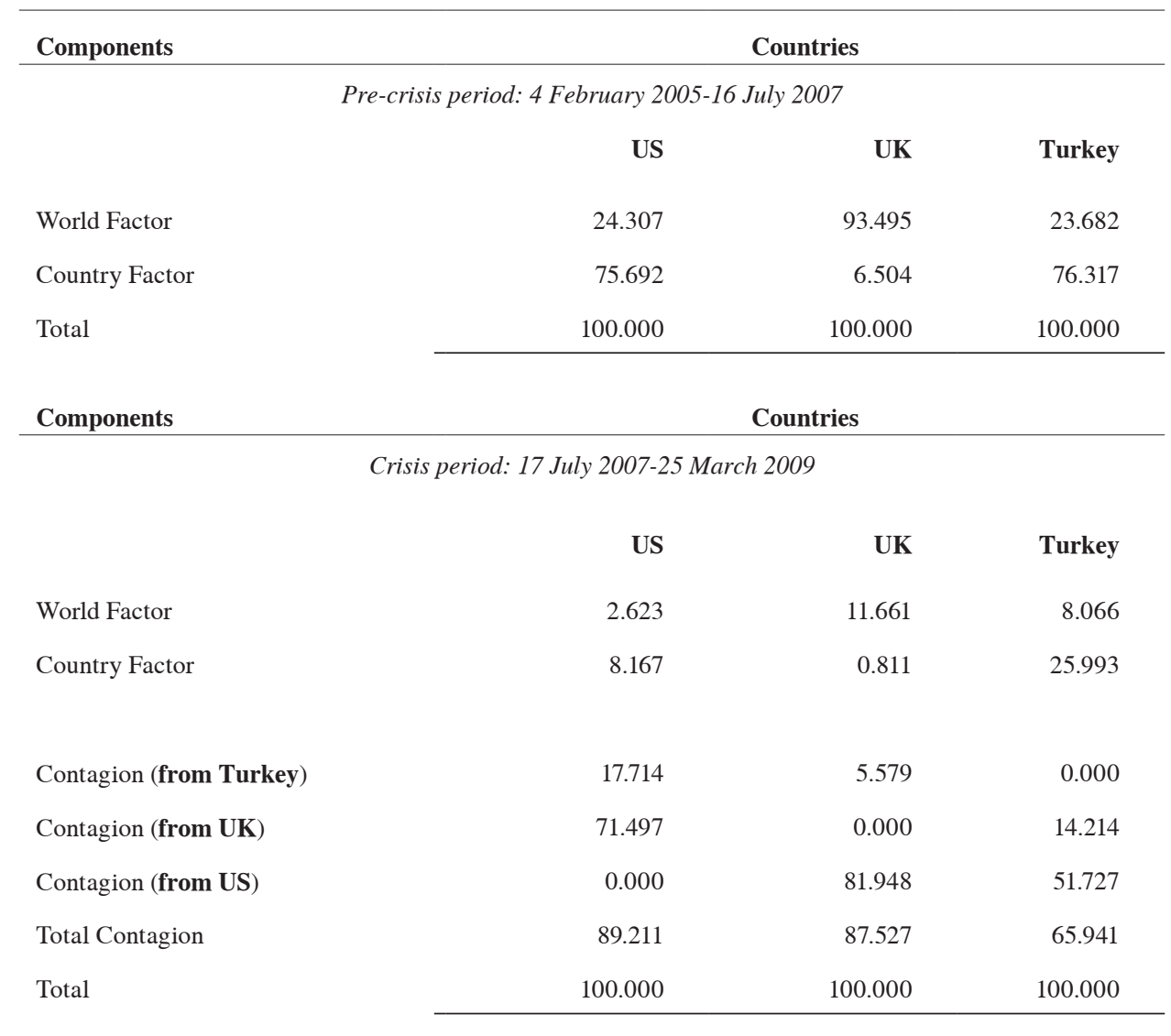

Figure 1.

The Role of the UK in Transferring Shock

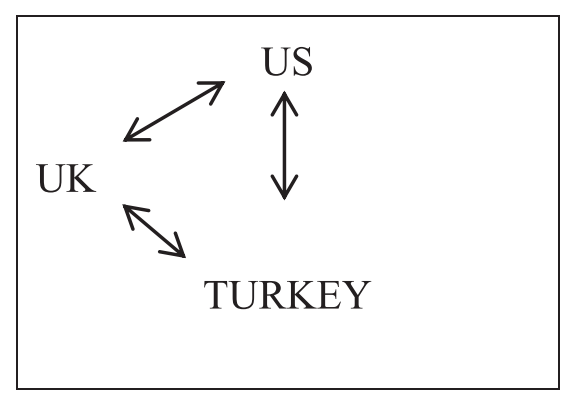


After confirming the contagion effect of the global credit crisis and its direction, we attempt to search for the channel in which the global credit crisis was transferred. In this context, we examine trade linkages among the three countries because some findings in the literature indicate that crises are transferred through trading (Bekaert, Harvey and $\mathrm{Ng}, 2005$ ) or financial channels (Van Rijckeghem and Weder, 2001). We create Table 6 using data from the US Census Bureau ${ }^{[5]}$ and CBRT

Table 6

Foreign Trade Data between 2004 and 2009 (million dollars)

\begin{tabular}{l|c|c|c|c|c|c}
\hline & \multicolumn{2}{|c|}{ Import } & \multicolumn{2}{c|}{ Export } & Export & Import \\
\hline & \multicolumn{2}{|c|}{ Turkey } & \multicolumn{2}{c|}{ Turkey } & US & US \\
\hline $\mathbf{2 0 0 4}$ & 4696.8 & 4316.8 & 4832.4 & 5540.3 & 36000.2 & 46273.8 \\
\hline $\mathbf{2 0 0 5}$ & 5371.3 & 4690.0 & 4898.8 & 5916.7 & 38587.8 & 51032.6 \\
\hline $\mathbf{2 0 0 6}$ & 6260.8 & 5137.5 & 5060.8 & 6814.3 & 45410.1 & 53513.0 \\
\hline $\mathbf{2 0 0 7}$ & 8166.0 & 5477.1 & 4170.6 & 8626.7 & 50228.7 & 56857.5 \\
\hline $\mathbf{2 0 0 8}$ & 11975.8 & 5323.9 & 4290.5 & 8158.8 & 53775.1 & 58619.2 \\
\hline $\mathbf{2 0 0 9}$ & 1937.2 & 656.2 & 735.7 & 1070.2 & 11748.6 & 10671.0 \\
\hline Ort & 6401.3 & 4266.9 & 3998.1 & 6021.1 & 39291.7 & 46161.1 \\
\hline
\end{tabular}

Source: CBRT-US Census Bureau

* Three months of data (January, February, and March)

Table 6 reflects the data for imports and exports between Turkey and the US, Turkey and the UK, the US and Turkey and the US and the UK for the period between 2004 and 2009. Although imports to the US from Turkey increased in many years, imports reached a maximum in 2006 and began to decrease in 2007. The foreign trade between Turkey and the UK reached a maximum in 2007 and decreased in 2008. The foreign trade between the US and the UK increased consistently between 2004 and 2009. Thus, Table 6 shows the possibility of the spread of the global crisis through trade channels.

${ }^{[5]}$ http://www.vob.org.tr. For ISE-30, the data are a continuous series of futures settlement prices that begin at the nearest contract month and continue until a contract reaches its expiration date. At this point, the next contract month is taken. These contracts comprise a continuous series of futures settlement prices that begin at the nearest contract month and generate the initial values for the continuous series until either the contracts reach their expiration dates or until the first business day of the actual contract month. At this point, the next contract month is taken (Engle and Colacito, 2006). 
Table 7

Foreign Trade Data between 2004 and 2009 (\%)

\begin{tabular}{c|c|c|c|c|c|c|c|c}
\hline & \multicolumn{2}{|c|}{ Export } & \multicolumn{2}{c|}{ Import } & \multicolumn{2}{c|}{ Export } & \multicolumn{2}{c}{ Import } \\
\hline & \multicolumn{2}{|c|}{ Turkey\& $^{*}$} & \multicolumn{2}{c|}{ Turkey\& } & \multicolumn{2}{c}{ US } & \multicolumn{2}{c}{ US $^{\#}$} \\
\hline & To US & To UK & From US & $\begin{array}{c}\text { From } \\
\text { UK }\end{array}$ & $\begin{array}{c}\text { To } \\
\text { Turkey }\end{array}$ & To UK & $\begin{array}{c}\text { From } \\
\text { Turkey }\end{array}$ & $\begin{array}{c}\text { From } \\
\text { UK }\end{array}$ \\
\hline $\mathbf{2 0 0 4}$ & $7.66 \%$ & $8.79 \%$ & $4.82 \%$ & $4.43 \%$ & $0.28 \%$ & $3.10 \%$ & $0.27 \%$ & $2.61 \%$ \\
$\mathbf{2 0 0 5}$ & $6.67 \%$ & $8.06 \%$ & $4.60 \%$ & $4.02 \%$ & $0.33 \%$ & $3.00 \%$ & $0.25 \%$ & $2.55 \%$ \\
$\mathbf{2 0 0 6}$ & $5.91 \%$ & $7.96 \%$ & $4.48 \%$ & $3.68 \%$ & $0.39 \%$ & $3.11 \%$ & $0.24 \%$ & $2.42 \%$ \\
$\mathbf{2 0 0 7}$ & $3.88 \%$ & $8.04 \%$ & $4.80 \%$ & $3.22 \%$ & $0.40 \%$ & $3.05 \%$ & $0.19 \%$ & $2.42 \%$ \\
$\mathbf{2 0 0 8}$ & $3.25 \%$ & $6.18 \%$ & $5.92 \%$ & $2.63 \%$ & $0.56 \%$ & $2.92 \%$ & $0.18 \%$ & $2.32 \%$ \\
$\mathbf{2 0 0 9 *}$ & $3.00 \%$ & $4.36 \%$ & $6.76 \%$ & $2.29 \%$ & $0.37 \%$ & $3.13 \%$ & $0.20 \%$ & $2.29 \%$ \\
$\mathbf{0 r t .}$ & $5.06 \%$ & $7.23 \%$ & $5.23 \%$ & $3.38 \%$ & $0.39 \%$ & $3.05 \%$ & $0.22 \%$ & $2.44 \%$ \\
\hline
\end{tabular}

* Three months of data (January, February, and March)

${ }^{\#}$ Source: US Census Bureau

However, by examining only Table 7, we cannot make an accurate deduction regarding the contagion channel. Thus, using the same databases (CBRT and the US Census Bureau), we create Table 7, which shows the percentages of foreign trade data between these countries. ${ }^{[6]}$ Table 7 shows that foreign trade relations among these countries are low compared with their total trades. For example, for the period between 2004 and 2009, average US exports to Turkey are $0.39 \%$, and average US imports from Turkey are $0.22 \%$. These results show that the probability of the global credit crisis being transferred through trade channels is weak.

\section{Conclusions}

The purpose of this study was to test the effect of the global credit crunch on the Turkish stock market by assessing of the role of the UK stock market in spreading the crisis to Turkey. The results confirm that the UK had an important role in transferring the volatility from the US to TR. In addition, the findings support the transnational contagion effect in the literature (Dungey and Martin, 2007). The presence of contagion is important for investors because the presence of contagion indicates asymmetrically distributed information and an increase in interaction between markets through financial liberalization, and this situation creates investment opportunities for international portfolio investors.

[6] To calculate the percentage of trade with the UK and the US of Turkey's total trade, exports and imports between Turkey and the US and between Turkey and the UK are divided by the total exports and imports of Turkey and then multiplied by 100. To calculate the percentage of trade between the UK and Turkey in the US's total trade, the exports and imports between the US and the UK and between the US and Turkey are divided by the total exports and imports of the US and then multiplied by 100 . 


\section{References}

Bae, K.H, Karolyi, G.A., and Stulz, R.M. (2003) “A New Approach to Measuring Financial Contagion," Review of Financial Studies, 16(3): 717-763.

Bekaert, G. and Hodrick, R. (1992). "Characterizing Predictable Components in Excess Returns on Equity and Foreign Exchange Markets," Journal of Finance, 47: 467-509.

Bekaert, G., Harvey, C.R., and Ng, A. (2005). "Market Integration and Contagion," Journal of Business, 78(1): 39-69.

Bekaert, G. and Harvey, C.A. (2003) "Emerging Markets Finance," Journal of Empirical Finance, 10(1-2): 3-55.

Bordo, M. and Eichengreen, B. (1999). "Is Our Current International Environment Unusually Crisis Prone?" in D. Gruen (ed.), Capital Flows and the International Financial System: 18-74. Sydney: Reserve Bank of Australia.

Calvo, S. and Mendoza, E. (2000). "Rational Contagion and the Globalization of Securities Markets," Journal of International Economics, 51: 79-113.

Cerra V. and Saxena, S.C. (2002). "Contagion, Monsoons, and Domestic Turmoil in Indonesia's Currency Crisis," Review of International Economics, 10(1): 36-44.

Chow, G.C. (1960). "Tests of Equality between Sets of Coefficients in Two Linear Regressions," Econometrica, 52: 211-22.

Corsetti, G., Pericoli, M., and Sbracia, M. (2002). "Some Contagion, Some Interdependence: More Pitfalls in Testing for Contagion," Mimeo, University of Rome.

Dungey M., Fry, R.A., Gonzalez-Hermosillo, B., and Martin, V.L., (2002a). "International Contagion Effects from the Russian Crisis and the LTCM Near Collapse." IMF Working Paper: WP/02/74.

-----, (2002b.). "The Transmission of Contagion in Developed and Developing International Bond Markets." Committee on the Global Financial System, Risk Measurement and Systemic Risk, Proceedings of the Third Joint Central Bank Research Conference: 61-74.

------, (2005). “Empirical Modeling of Contagion: A Review of Methodologies," Quantitative Finance, 5(1): 9-24.

------, (2006). "Contagion in International Bond Markets During the Russian and LTCM Crises," Journal of Financial Stability, 2(1): 1-27.

Dungey, M. and Martin, V.L. (2004). "A Multifactor Model of Exchange Rates with Unanticipated Shocks: Measuring Contagion in the East Asian Currency Crisis," Journal of Emerging Market Finance, 3(3): 305-330.

, (2006). "Contagion in International Bond Markets During the Russian and LTCM Crises," Journal of Financial Stability, 2(1): 1-27.

-----, (2007). “Unravelling Financial Market Linkages During Crises," Journal of Applied Econometrics, 22(1): 89-119.

Dungey, M., Fry, R.A., and Martin, V.L. (2004). "Currency Market Contagion in the Asia-Pacific Region," Australian Economic Papers, 43(3): 379-395.

-----, (2006). “Correlation, Contagion and Asian Evidence,” Asian Economic Journal, 5(2): 32-72.

Dungey, M. and Tambakis, (2005). Indentifying International Financial Contagion, Oxford University Press. 
Dungey, M. (2009). “The Tsunami: Measures of Contagion in the 2007-08 Credit Crunch,” CESifo Forum, 9(4) 33-34.

Dungey, M. and Yalama, A. (2010). "Detecting Contagion with Correlation: Volatility and Timing Matter," Centre for Financial Analysis and Policy," Working Paper-No: 35, May-2010, University of Cambridge.

Eichengreen, B., Rose, A.K., and Wyplosz, C. (1995). "Exchange Market Mayhem: The Antecedents and Aftermath of Speculative Attacks," Economic Policy, 21: 249-312.

------, 1996). “Contagious Currency Crises,” NBER Working Paper, 5681.

Engle, R.F. and Colacito, R., (2006). "Testing and Valuing Dynamic Correlations for Asset Allocation," Journal of Business and Economic Statistics, 24(2): 238-253.

Favero, C.A. and Giavazzi, F. (2002). "Is the International Propagation of Financial Shocks Non-linear? Evidence from the ERM," Journal of International Economics, 57(1): 231-246.

Forbes, K. and Rigobon, R. (2002). "No Contagion, only Interdependence: Measuring Stock Market Co-movements," Journal of Finance, 57(5): 2223-2261.

Glick, R. and Rose, A.K. (1999). “Contagion and Trade: Why Are Currency Crises Regional?” Journal of International Money and Finance, 18(4): 603-617.

Grubel, H.G. and Fadner, R. (1971). “The Interdependence of International Equity Markets," Journal of Finance, 26: 89-94.

Hamilton, J.D. (1989). "A New Approach to the Economic Analysis of Nonstationary Time Series and the Business Cycle," Econometrica, 57: 357-384.

Hansen, B.E. (1992). "The Likelihood Ratio Test under Non-standard Conditions: Testing the Markov Trend Model of GNP," Journal of Applied Econometrics, 7: S61-S82.

Horta P., Mendes, C., and Vieira, I. (2008). "Contagion Effects of the US Subprime Crisis on Developed Countries," CEFAGE-UE Working Paper.

Kaminsky, G.L. and Schmukler, S.L., (1999). "What Triggers Market Jitters? A Chronicle of the Asian Crisis," Journal of International Money and Finance, 18: 537-560.

Kaminsky, G.L. and Reinhart, C.M. (1999). "The Twin Crises: The Causes of Banking and Balance of Payments Problems," USA Economic Review, 89(3): 473-500.

-----, (2007) "The Centre and the Periphery: The Globalization of Financial Turmoil," in Reinhart, C. Vegh. and A. Velasco (eds.), Capital Flows, and Stabilization: Essays in Honor of Guillermo Calvo, MIT Press.

King, M. and Wadhwani, S. (1990). "Transmission of Volatility Between Stock Markets," Review of Financial Studies, 3(1): 5-33.

Kodres, L.E. and Pritsker, M. (2002). "A Rational Expectations Model of Financial Contagion," Journal of Finance, 57(2): 768-799.

Longstaff, F.A. (2008). “The Subprime Credit Crisis and Contagion in Financial Markets," UCLA Working Paper.

Lowell, J., Neu, C.R., and Tong, D. (1998). "Financial Crisis and Contagion in Emerging Market Countries," Monograph RAND.

Sharpe, W. (1964), "Capital Asset Prices: A Theory of Market Equilibrium Under Conditions of Risk," Journal of Finance, 19: 425-442. 
Stoll, H.R., and Whaley, R.E., (1990). "The Dynamics of Stock Index and Stock Index Futures Returns," Journal of Financial and Quantitative Analysis, 25: 441-468.

Tai, C.S. (2003). "Looking for Contagion in Currency Futures Markets," Journal of Futures Markets, 23(10): 957-988.,

-----, (2004). "Looking for Risk Premium and Contagion in Asia-Pacific Foreign Exchange Markets," International Review of Financial Analysis, 13(4): 381-409.

Wu, C., Li, J. and Zhang, W. (2005). "Intradaily Periodicity and Volatility Spillovers between International Stock Index Futures Markets," The Journal of Futures Markets, 25(6): 553-585.

Van Rijckeghem, C.V. and Weder, B. (2001), “Sources of Contagion: Is It Finance or Trade?" Journal of International Economics, 54: 293-300. 